\title{
Multi-stage crustal accretion by magmatic flare-ups and quiescence intervals in the western margin of the São Francisco Craton: U-Pb-Hf and geochemical constraints from the Almas Terrane
}

\author{
AirTON N. C. DiAs ${ }^{1 *}$, MARCO A. C. MARTINS- \\ FERREIRA $^{2}$; FARID CHEMALE JR. ${ }^{3}$; JOSÉ E. G. CAMPOS ${ }^{4}$ \\ VINICIUS Q. PEREIRA ${ }^{1}$ \\ ${ }^{1}$ DFQM, CCTS, UFSCar, 18052-780, Brazil (*corresp: \\ diasanc@ufscar.br; viniciusqueiros@gmail.com) \\ ${ }^{2}$ FCT, UFG, Brazil (martinsmarco@gmail.com) \\ ${ }^{3}$ PPGG, UNISINOS, Brazil (faridchemale@gmail.com) \\ ${ }^{4} \mathrm{IG}$, UnB, 70910-900, Brazil (eloi@unb.br)
}

The global plate tectonic regime in early Paleoproterozoic times is highly debated. The interval $2.45-2.2 \mathrm{Ga}$ is known for a minima in juvenile magmatism, but this is not a global phenomenon. New results of whole-rock geochemistry and $\mathrm{U}-\mathrm{Pb}-\mathrm{Hf}$ analysis in igneous and detrital zircons, allied with existing isotopic and geophysical data, allow to identify and constrain the duration of magmatic flare-up and quiescence events in the western São Francisco Paleoplate. Detrital zircon $\mathrm{U}-\mathrm{Pb}$ age distribution for greenstone quartzites show peaks at 2.65, 2.47, 2.39, 2.27 and $2.23 \mathrm{Ga}$. Igneous samples yield ages indicating three magmatic events, an older with ages ca. $2476.4 \pm 9$ Ma, 2475.5 \pm 5 Ma, 2462 $\pm 13 \mathrm{Ma}$, an intermediate ca. $2390 \pm 14 \mathrm{Ma}$, and a younger ca. $2235 \pm 26$ Ma, 2211 \pm 9 Ma, 2204 \pm 6 Ma, $2202 \pm 5 \mathrm{Ma}, 2201 \pm 5 \mathrm{Ma}$, all presenting magmatic arc geochemical signatures. Xenoliths of quartzite and volcanic tuff from the upper greenstone sequence (Morro do Carneiro Fm.) are hosted in the 2211 \pm 9 Ma tonalite and the maximum depositional age of this basin is dated ca. $2234 \pm 12 \mathrm{Ma}$, providing a well constrained age and indicating a syn-orogenic setting for this basin. Altogether, the studied rocks record an accretionary orogeny with four distinct episodes: Episode S1: 2.52-2.46 Ga, $\varepsilon_{\mathrm{Hf}(\mathrm{t})}$ values from +0.57 and +6.36 ; Episode $\mathrm{S} 2: 2.43-2.37 \mathrm{Ga}$, $\varepsilon_{\mathrm{Hf}(\mathrm{t})}$ values from +0.10 to +4.30 ; Episode R1: $2.32-2.26 \mathrm{Ga}$, $\varepsilon_{\mathrm{Hf}(\mathrm{t})}$ values from +1.61 to -7.23 (from detrital zircons); Episode R2: $2.24-2.20 \mathrm{Ga}, \varepsilon_{\mathrm{Hf}(\mathrm{t})}$ values from +0.39 to -2.73 . These early Paleoproterozoic accretionary orogenies mark the onset of amalgamation of the São Francisco continental paleoplate that surrounds the craton, with accretions of an exotic micro-block and continental magmatic arcs, indicating evolution from dominant Siderian juvenile magmatism to Rhyacian crustal magmatism. These patterns show striking similarities to the orogenies in the Mineiro Belt and the North China Craton. 